\title{
DESIGNING ISLAMIC VALUES INTEGRATION INTO SOCIOLOGY LEARNING
}

Tatang Hidayat

Sekolah Tinggi Ilmu Bahasa Arab (STIBA) Ar Raayah

Jl. Perintis Kemerdekaan Kabupaten Sukabumi, Jawa Barat, Indonesia, 43161

Email: tatanghidayat@arraayah.ac.id

\section{Ahmad Syamsu Rizal}

Universitas Pendidikan Indonesia

Jl. Dr. Setiabudhi No. 299 Bandung, Jawa Barat, Indonesia, 40154

Emai: rizal@upi.edu

\author{
Aam Abdussalam \\ Universitas Pendidikan Indonesia \\ Jl. Dr. Setiabudhi No. 299 Bandung, Jawa Barat, Indonesia, 40154 \\ Email: aam86@upi.edu
}

\author{
Ahmad Ghiyats Fawwaz \\ University of Jordan \\ Queen Rania St., 11942 Amman - Jordan \\ Email: ahm8181297@fgs.ju.edu.jo
}

Received: 04, 2020. Accepted: 06, 2020. Published: 06, 2020

\begin{abstract}
The effort to integrate Islamic values into learning has both attracted Islamic scholars to discuss and led them to offer their models which are open to examine. The purpose of this study is to discover a hypothetical model of integration planning of Islamic values into learning sociology at SMA (Sekolab Menengah Atas/Senior High School) PGII (Persatuan Guru Islam Indonesia/The Association of Indonesian Islamic Teachers) 2 Bandung. This present study employed a qualitative approach and a descriptive method in the form of case study. The data were collected using techniques namely: interviews, observation, and study documentation. The data were analysed through several steps namely: reducing, coding, displaying, interpreting of findings, and conclusion drawing. Based on the results of the study, the planning of the integration of Islamic values in learning sociology at SMA PGII 2 Bandung was applied through the use of the 2013 curriculum instrument. This integration occurred in the level of justification models. This is to say that the Quran was used as a justification tool for the learning contents of sociology learning. In this regard, the monotheism paradigm was brought into existence in the learning phases namely beginning, middle, and end of learning. Those phases served as efforts to create a religious atmosphere so that were designed and planned in order to reach Islamic values integration in sociology learning.
\end{abstract}

Keywords: Integration, Islamic Values, Learning Design, Sociology

\begin{abstract}
ABSTRAK
Upaya untuk mengintegrasikan nilai-nilai Islam ke dalam pembelajaran telab menarik para cendekiawan Islam untuk berdiskusi dan mengarabkan mereka untuk menawarkan model-model mereka yang terbuka untuk diuji. Tujuan dari penelitian ini adalab untuk menemukan model hipotesis perencanaan integrasi nilai-nilai Islam ke dalam pembelajaran sosiologi di SMA Menengah Atas (Persatuan Guru Islam Indonesia) 2 Bandung. Penelitian ini menggunakan pendekatan kualitatif dan metode deskriptif dalam bentuk studi kasus. Data dikumpulkan dengan menggunakan teknik yaitu: wawancara, observasi, dan studi dokumentasi. Data dianalisis melalui beberapa langkah yaitu: mengurangi, mengkode, menampilkan, menafsirkan temuan, dan menarik kesimpulan. Berdasarkan hasil penelitian, perencanaan integrasi nilai-nilai Islam dalam pembelajaran sosiologi di SMA PGII 2 Bandung diterapkan melalui penggunaan instrumen kurikulum 2013. Integrasi ini terjadi di tingkat model justifikasi. Hal ini dimaksudkan untuk mengatakan bahwa Al-Quran digunakan sebagai alat pembenaran untuk isi pembelajaran pembelajaran sosiologi. Dalam hal ini, paradigma monoteisme muncul dalam fase pembelajaran yaitu awal, tengah, dan akhir pembelajaran. Fase-fase tersebut berfungsi sebagai upaya untuk menciptakan suasana keagamaan sehingga dirancang dan direncanakan untuk mencapai integrasi nilai-nilai Islam dalam pembelajaran sosiologi.
\end{abstract}

Kata Kunci: Integrasi, Nilai Islam, Desain Pembelajaran, Sosiologi 


\section{INTRODUCTION}

Islamic teachings cover all aspects of life, including worship, morals, economics, education and so on. In education, Islamic values are expected to offer a good contribution if they are included and integrated into the teaching and learning process. Purwati et al. (2018) argued that the integration of Islamic values in learning is one of the strategies that can be applied to improve students' learning outcomes. Learning science integrated with Islamic values provides opportunities for students to connect science with their concepts and experiences in real life as Muslims, so students can feel that their learning is meaningful.

Makruf (2009) asserts that Islamic education experts also consider that the education system adopted in Indonesia adheres to a dualistic education system. First, the Islamic education system consists of pesantren (Islamic boarding schools) and madrasab that are at all levels under the Ministry of Religion's auspices. Second, there is a secular education system. Moreover, it strongly relates to the modern traditions introduced by the Dutch pagan colonial government, which places it under the Ministry of Education and Culture.

The problem of education in Indonesia can be associated with several factors. The secular education paradigm and the materialism education system are deemed as the main causes of the destruction of education in Indonesia. Secular paradigms cause adverse effects in education, like opening the door to atheism, weakening the values of faith, and spreading moral decay (Bafadhol, 2015; Suaidi, 2014). Therefore, solutions are needed to study and examine the dichotomy between secular and religious science in the planning of learning at the elementary/junior high/high school level and the equivalent in Indonesia.

The basic theory of the integration of Islamic values on learning in this research is based on the idea of value integration developed by Kartanegara (2005). Kartanegara (2005) ensures that the concept of Tauhid has become the most fundamental principle in Islamic teachings. To integrate its in science, the concept of Tauhid became the principal principle of Islamic epistemology. Thus, the integration of this science must be based on the concept of Tauhid derived from the sentence Là Iläha Illalläh.

A universal truth is offered in every single subject, including sociology learned in the school. The existence of universal truth values in sociology so far has not been widely applied. The reality of sociological learning content studied in Sekolab Menengah Atas (Senior High School) is similar to that of other general subjects. In sociology learning, the values of character must be internalized by teachers to students. The values of the character can be integrated with Islamic values to build Islamic character through sociology learning. This phenomenon can be challenging since the subject has been value free and secular in nature. Also, the theories are also mostly taken from the west and built upon western philosophy. As a consequence, it is very dangerous if this discipline is taught to Muslim students. Therefore, it is necessary to plan the integration of Islamic values in learning sociology as a means of fostering an Islamic character.

Previous researchers have done studies on Islamic values integration in learning. For example, Taskun (2014) investigated "An exploratory examination of Islamic values in science education: Islamization of science teaching and learning via constructivism". The study focused on integrating Islamic values into the teaching and learning process. Afandi (2011) studied "Integration of Character education in the learning of IPS (Ilmu Pengetabuan Sosial/Social Science) in elementary School". It offered a model of integration of character education in the learning of social sciences in elementary school. In a similar vein, Darmana (2012) exploited the integration of Taubid in science learning. The issue of Islamic values integration into social sciences remains understudied. According to these motivations, the study investigated designing Islamic values integration in sociology learning in high schools. 


\section{METHOD}

This research is a part of larger projects on the integration of Islamic values in sociology learning. This study's main objective is to investigate a hypothetical model of designing the integration of Islamic values in learning sociology as a means of fostering an Islamic character. This present study employed a qualitative approach in the form of a case study.

To collect the data, interviews were conducted to several figures like the principal of SMA PGII 2 Bandung, deputy principal of curriculum, deputy principal of students, deputy principal of the school of resources, teachers of sociology, teacher of Islamic religious education and student representatives. Observation techniques were applied to collect data related to space, place, participants, and activities in the school. It was done mainly to observe teacher and student activities in class. Other observations took place in the mosque, teachers' rooms, canteen, and other places. The data was also collected from the documentation. The documents included the school's report on its performance in 2018, the school history, vision, mission, objectives, teachers' data, education personnel, facilities and infrastructure, school rules, school work programs, subject schedules, learning devices in sociology, school brochure, organizational structure, the school website, and others.

The data were analyzed through several steps including data reduction, data coding, data display, interpretation of findings, and conclusions. Triangulation was applied to ensure the reliability of the data collection in this study (Creswell, 2015)The data are delivered in the form of images and charts, describing with brief descriptions and analysed to spot data relationship.

\section{RESULTS AND DISCUSSION}

This study aimed to investigate a hypothetical model of designing Islamic values integration into sociology learning at SMA PGII 2 Bandung. The data of the school program to design Islamic value integration into sociology learning will be first presented and followed by the design of the integration of Islamic values in sociology learning. In the end, a hypothetical model of designing Islamic values integration is delivered.

\section{The school program to design Islamic values integration in learning}

This study found that the school designed the integration of Islamic values in sociology learning at SMA PGII 2 Bandung, and it used a 2013 curriculum that was integrated with the school's distinctive curriculum. The curriculum was jointly made by the general curriculum developing team and the religious curriculum developing team. The results were integrated into the PGII 2 Bandung High School curriculum. Educational program planning starts in May each year. Each unit under the auspices of YP PGII consisting of SMP, SMA, and SMK has begun formulating programs for the new academic year based on the RKJM (Rencana Kerja Jangka Menengah/ Medium-Term Work Plan) which is made every four years. Each semester the program is formulated with the objectives to confirm what was planned at the beginning of the year in order to remind what must be done by the team. After the curriculum is created, an IHT (In House Training) training is held by YP PGII every year. Each unit of YP PGII discussed their respective programs.

Based on the document study, this study found that educational experts from UIN Sunan Gunung Djati, UPI, and other tertiary institutions delivered IHT training, and they designed learning innovations that were integrated with Islamic values. After IHT training activities were carried out, the sociology teachers designed learning preparation consisting of information covering effective weeks, semester programs, annual programs, competency standards and basic competencies, basic competency programs, syllabus, lesson plans, and KKM (Kriteria Ketuntasan Minimum/Minimum completeness criteria). 
Based on the interviews, this study found that to integrate Islamic values in sociology learning tools, the teachers consulted with PAI teachers. In the RPP (Rencana Pelaksanaan Pembelajaran/Lesson plan) sociology learning material was linked with Islamic values contained in the verses of the Qur'an. This integration was aimed at educating students and familiarizing Islamic values in the learning process. Almost every teacher consulted PAI (Pendidikan Agama Islam/Islamic Religious education) teachers to find propositions relating to the teaching material. Typically, the teachers submitted a chapter of sociology learning material to the PAI teacher with the objectives of finding out relevant and supporting the Qur'an verses and hadith related to the sociology learning material.

It is not an easy task to design the integration of Islamic values in sociology learning. Based on the interviews with the teachers, this study found that they had difficulties in carrying out this mission. Their obstacles related to understanding the verses of the Qur'an that are relevant to explain the learning material of sociology. This problem occurred because they used to study in formal schools, not pesantren or madrasah, so they did not master the Islamic knowledge. To overcome their obstacles, the teachers spent their time learning it. Another effort to strive was to consult PAI teachers concerning Islamic values integration in sociology learning material.

The program to design the integration of Islamic values in sociology learning was supported by several factors, namely the school environment, rules, and religious atmosphere. Based on the observation, to name a few, this study found that the way students dressed were under the Islamic teachings. Students are required to perform reading Asmaul Husna, Alquran, Khatmil Koran, and Prayers before learning. They also took part in the religious mentoring, Islamic youth groups, habituation of prayer in the congregation 'at the mosque, and other religious school culture. Those supporting factors have paved the way for the integration of Islamic values in sociology learning.

Many advantages can be achieved by designing the integration of Islamic values in sociology learning. Students received conceptual knowledge and, at the same time, they had the opportunity to implement the concept in the school. In the conceptual level, the verses of Qur'an are included in the lesson plan so that it has its own distinction compared to other sociology learning in other schools. Islamic values can be integrated into sociology learning such as religious values, honesty, discipline, responsibility, caring (cooperation, cooperation, tolerance, peace), polite, responsive, and pro-active.

Based on the observation of the document, this study found that sociology learning applied a scientific approach integrating Islamic values in sociology learning material. For a learning model, the teachers applied discovery learning and problem-based learning. When it comes to the method used, learning involved question and answer, interview, discussion, and role-playing. To design the integration of Islamic values in learning sociology, the teachers used the sociology textbook from a particular publisher, LKS (Lembar Kerja Siswa/Students' worksheet), and the personal experiences of teachers and students as well. Based on the interview, the teachers provided extra explanation for the sociology theory that is contrary to the Islamic concept.

The school applied the procedures to ensure the credibility of the sociology learning material. The lesson plan was checked by the principal and deputy principal of the curriculum every year, and they were followed by an evaluation from the school's principal. For example, if some lesson plans in sociology were not good, the teachers were required to revise immediately. This could be realized by providing a letter of assignment from the principal to the sociology teacher to improve the lesson plans. Then the sociology teacher must immediately revise the lesson plans made. 
The school Foundation of PGII invited education experts to explain materials in IHT activities. The invited experts were persons who understood the concept of integration of Islamic values in science. Based on the observations, this study found that the experts invited by the school had not achieved the objectives of Islamic values integration in sociology learning. This study found no books claimed to be recognized as Islamic sociology books and books on sociology for high school levels that had been integrated with Islamic values.

Based on researchers' observations, the curriculum and learning culture at SMA PGII 2 Bandung are already integrated with Islamic values. That is to say, there are some shortcomings. One of them is related to the learning culture that has not been integrated as a whole. It is found that there are learning cultures that are still not following Islamic values.

During sociology learning, the references are still general and have not been integrated with Islamic values. Unsurprisingly, it happens since the handbooks on sociology at the high school level are in a very small number, and they have not been integrated yet with Islamic values. Therefore, this problem leads sociology teachers to encounter a number of difficulties in integrating Islamic values in the realm of teaching content substance. Moreover, the available references in this subject are still secular. Hence, sociology teachers must make their own efforts to integrate Islamic values into sociology teaching contents.

Meanwhile, in terms of learning methods, sociology teachers still use conventional learning methods adopted from the west. It happens because sociology teachers do not know of any learning methods originally postulated by Islamic scholars. The IHT activities should be carried out two to four times a year. They are carried out as a means of fostering teachers on an ongoing basis in integrating Islamic values in learning sociology. Moreover, the teachers assume that this integration is complicated. It is undeniable that if the IHT activities are only conducted once a year and not followed by any coaching, the sociology teacher will encounter a series of difficulty in making sociology learning tools integrated with Islamic values. Such difficulties are also caused by the input of the sociology teacher itself, who comes from the campus, which does not integrate Islamic values into sociology. Thus, when a sociology teacher joins SMA PGII 2 Bandung, he or she must start from the beginning to work on making a sociology learning tool that is integrated with Islamic values.

\section{The design of Islamic values integration in sociology learning}

Having described the school program to Integrate Islamic values in sociology learning in the previous section, this article is now delivering the design of Islamic values integration in sociology learning. As one of the phases of integrating Islamic values into sociology learning, this study proposed the paradigm of monotheism and the Quran, which can be applied in sociology learning stages as follows:

Table 1. Integrative Lesson Study of Sociology Learning

Introductory Activities (15 Minutes)

\footnotetext{
Teacher:

Orientation

- Conducting an opening by greetings. Creating a religious atmosphere with the recitation of Asmaul Husna, kalimah Thoyyibah sentence, reading Al- Quran, and prayers for learning.

- Extending thanks to God Almighty.

- Checking the attendance of students as a disciplined attitude.

- Instructing to prepare physically and psychologically by presenting and fixing intentions in initiating learning activities.

Apperception

- Linking the to-be-conducted teaching contents/themes/learning activities with the experiences of students in the past.

- Reminding the prerequisite learning contents by questioning students.

- Asking questions that are related to the to-be-done lesson.
} 


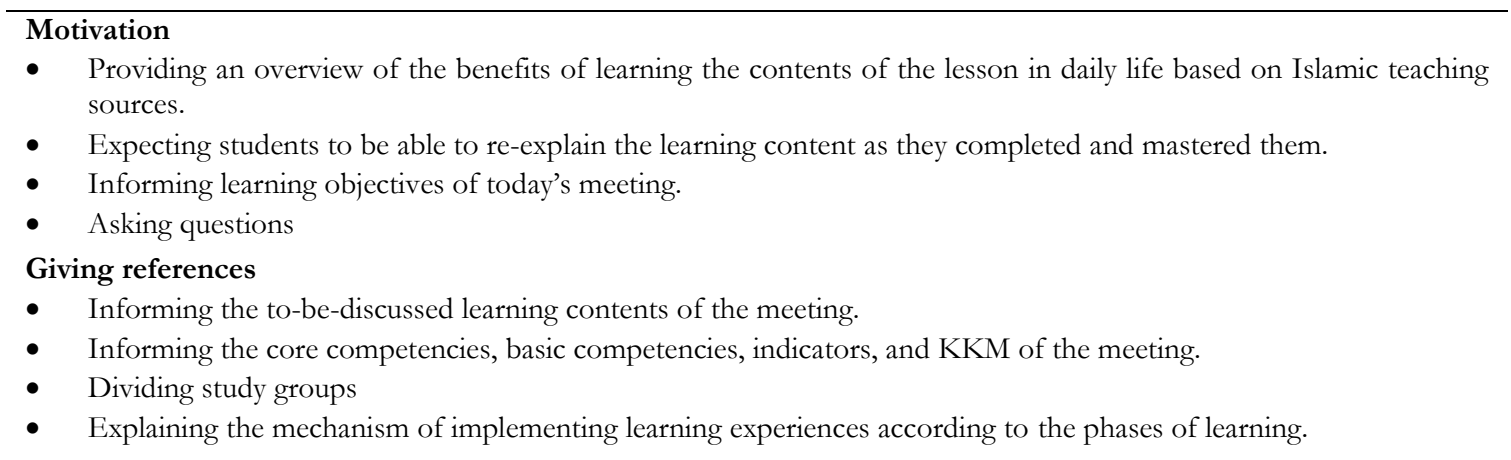

\begin{tabular}{lc}
\hline & Main Activities (150 Minutes) \\
\hline $\begin{array}{l}\text { Syntax } \\
\text { Learning } \\
\text { Model }\end{array}$ & Learning Activities \\
\hline
\end{tabular}

Stimulation LITERACY ACTIVITIES

Students are motivated and stimulated as a means of drawing attention to the learning topic under discussion by:

- Seeing (with or without tools)

Displaying the verses of the Quran, prophetic sayings of the Prophet, Islamic sociological learning contents, and sociological learning contents in the form of relevant pictures/photos, and videos.

\section{IDI AL-HUJURAT: 9}

"And if two factions among the believers should fight, then make settlement between the two. But if one of them oppresses the other, then fight against the one that oppresses until it returns to the ordinance of Allah. And if it returns, then make settlement between them in justice and act justly. Indeed, Allah loves those who act justly (AlHujūrat [49]: 9)

\section{- Observing}

The to-be discussed content worksheet.

Providing examples of the to-be-discussed teaching contents that can be developed by students from the interactive media, and so on.

\section{- Reading}

This literacy activity is carried out at home and school by reading the learning contents from textbooks, or other supporting books, such as sociology books authored by Muslim thinkers and the internet/learning contents related to the to-be discussed contents.

\section{- Writing}

Writing the summary of the observation results and learning contents related to the to-be discussed content.

\section{- Listening}

Giving the to-be-discussed learning contents by teachers.

\section{- Speaking}

Explaining the introduction of activities in general on the learning contents as a means of instilling the attitudes of gratitude, sincerity, discipline, accuracy, and information discovery.

\section{Problem CRITICAL THINKING}

statements Teachers allow students to identify as many questions as possible related to the presented picture (Problem and will be answered during the learning activities. For example:

Identification) - Asking questions on the learning contents:

What has not been understood from the discussion and observation or questions presented to get additional information about what is observed (starting from factual questions to hypothetical questions). This activity aims at developing creativity, curiosity, and ability to formulate questions and critical thinking as a means of creating smart live and lifelong learning.

Data LITERACY ACTIVITIES

collection Students collect relevant information to answer identified questions through the activities of:

- Observing objects/events

Observe the learning contents understudy in the form of pictures/videos/slides of the presentation presented and then interpreted.

\section{- Reading other sources except for textbooks}

Conducting literacy activities consistently by searching and reading various references from various sources in order to increase knowledge and understanding of the learning contents under study. 


Activities
Compiling a list of questions regarding the learning contents that are not yet understood during
observing and reading activities for teachers related to the learning contents under study.
Asking questions related to the arranged learning contents in the list of questions to the teachers.
COLLABORATION
Students are divided into several groups to:
Students and teachers collectively discuss the examples in textbooks regarding the learning
contents under discussion.
- Collect information
Recording all information related to the learned learning contents taken from the textbooks by
using neat writing and good and correct Indonesian.
Students communicate verbally or present the learning contents confidently based on their
understanding.
Students respond actively to other groups to obtain new knowledge that can be used as the
learning content for group discussion later. In addition, it is also encouraged to use scientific
methods contained in the students' handbooks or worksheets provided carefully as a means of
developing an accurateness, honesty, politeness, respect of other people' opinions, ability to
communicate, implementation of the ability to gather information through a variety of ways
understudy, development of learning habits, and lifelong learning.

\section{Data COLLABORATION and CRITICAL THINKING}

processing In their group, students discuss and process the data as the results of observation via:

- Discussing data on the to-be-discussed learning contents.

- Processing information of the learning contents collected from the results of previous activities/classroom meetings and the results of observing activities and activities that are currently taking place with the help of questions on the worksheet.

- Students work on a number of questions on the learning contents under discussion.

Verification CRITICAL THINKING

Students discuss the results of their observations and verify the results of their observations using data or theories taken from the sourcebook through activities:

- Adding breadth and depth of learning contents to processing information as a means of searching solutions from various sources that have different and contrary opinions. This activity aims to develope honesty, accuracy, discipline, obedience, hard work, ability to apply procedures, and inductive and deductive thinking to prove the learning contents under discussion. It is done via: Students and teachers jointly discuss the answers to the questions completed by students.

Generalization COMMUNICATION

Students discuss on:

- Conveying the discussion results on the discussed learning contents in the form of conclusions based on the results of the analysis verbally, in writing, or other media. This activity aims at developing the attitudes of honesty, conscience, tolerance, systematic thinking ability, and politeness in expressing opinions.

- Presenting the results of group discussions classically on the learning contents under discussion.

- Expressing opinions on the presentations regarding the learning contents under discussion and being responded to by the presenting group.

- Asking questions on the presentations, and other students are allowed to answer them.

CREATIVITY

- Summing up the important points that emerged during the learning activities in the form of:

The report on the observations in writing about the learning contents under discussion.

- Answering questions regarding the learning contents contained in the students' handbooks or worksheets that have been provided in advance.

- Asking questions about things that are not yet understood, or the teacher asks a few questions to students relating to the teaching contents at the end of the learning session.

- Completing the competency test of the learning contents in the students' handbooks or worksheets that have been provided individually. It is used to check students' mastery of the learning contents of the subject. 
- Explaining sociological learning contents that are contrary to the Islamic values and then explaining to the concept of sociology from Muslim thinkers.

- Guiding students to conclude the conducted learning and raising awareness about grace and compassion, greatness and power, and gratitude to Allah Subhānabu Wata'älâ.

Note: During the learning process, the teacher observes the attitude of students, including the attitudes of nationalism, discipline, self-confidence, and honesty, toughness in facing the problem of responsibility, curiosity, and care for the environment.

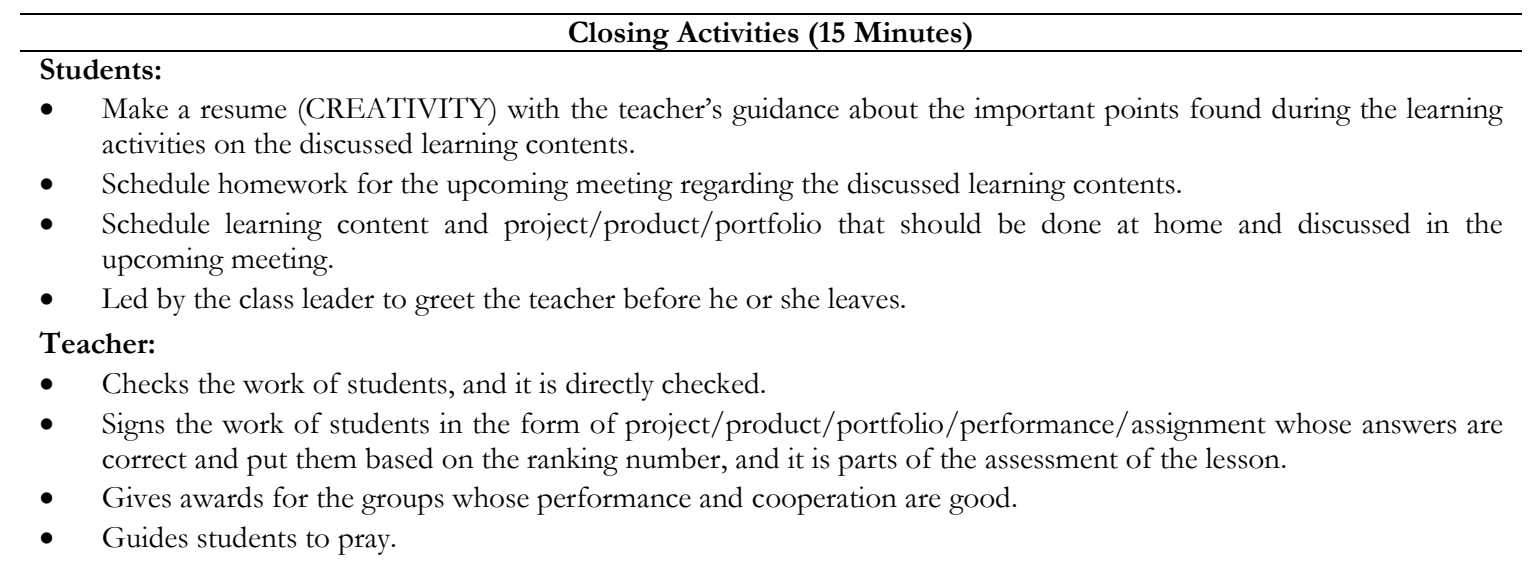

The above table show how the design of Islamic values integration in sociology learning stages. Each activity contains several details to consider. Islamic values are integrated where they fit the learning activities.

\section{The Hypothetical Model of Design of Integration Islamic Values in Sociology Learning}

In line with the above table, it is necessary to have a discovery model for developing the integration planning of Islamic values into sociology learning at SMA PGII 2 Bandung. This study proposes a hypothetical model chart on the design of the integration of Islamic values into sociology learning to foster an Islamic character at SMA PGII 2 Bandung.

In this hypothetical model, Islamic Values integration in sociology learning includes the concept of integration's improvement and Islamization of Science from Mulyadhi Kartanegara, Al-Attas and Al-Faruqi. Integration is applied in the introduction of learning, the motivation of learning, Islamic sources for sociology, learning core, and the need to create a religious atmosphere. 


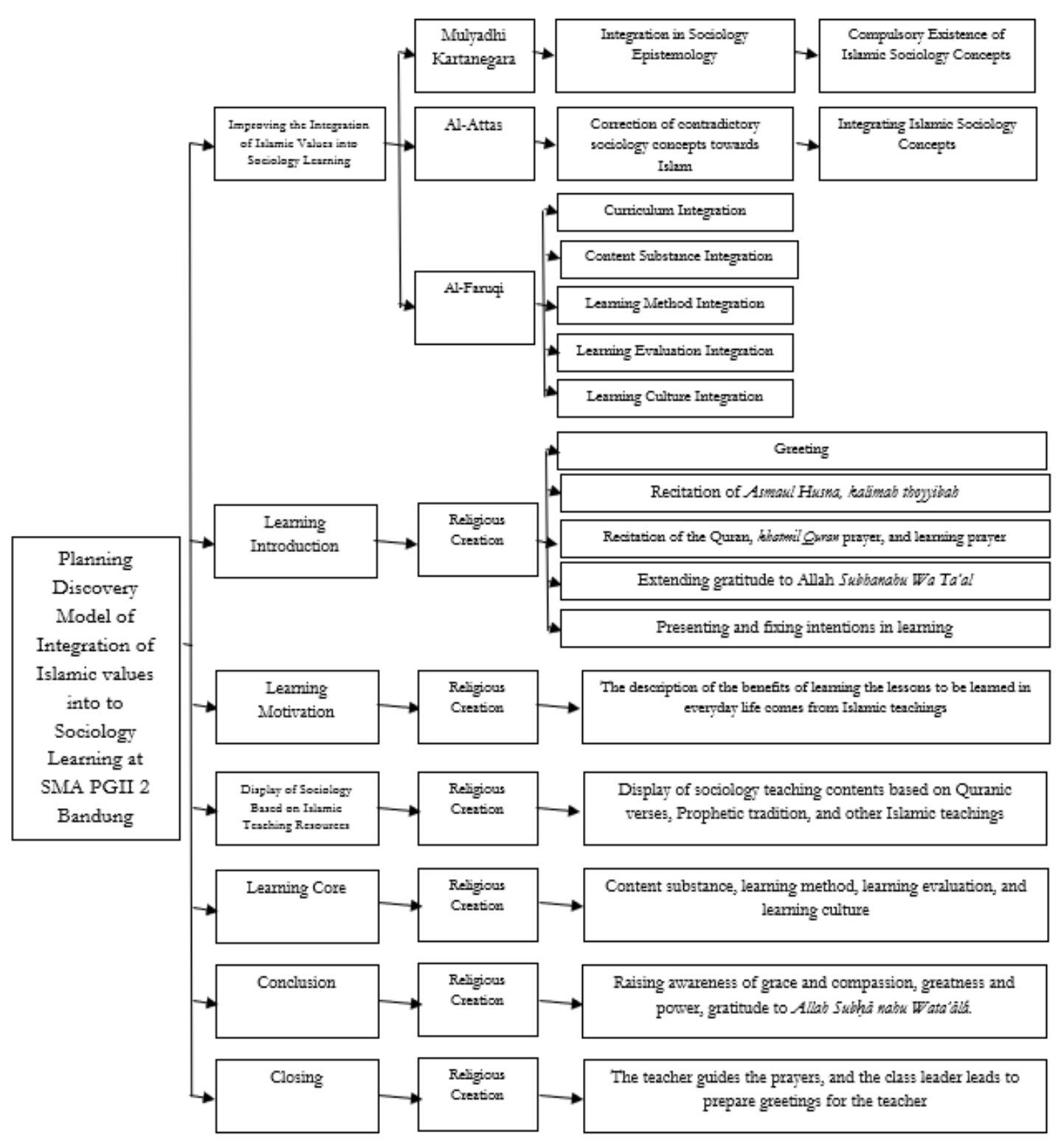

Figure 1. Hypothetical Model the Integration Design of Islamic Values into Sociology Learning at SMA PGII 2 Bandung

The above chart demonstrates how Islamic values are integrated into sociology learning. To provide a bigger picture for the readers, in the next section, this article will provide discussion related to the results of this study.

Mufid (2014) notes that the responses uttered by Islamic scholars related to Islamic and secular science is divided into three typologies, namely restorationism, reconstruction, and reintegration. The unity between these two types of science tends to be interconnected and integrated, and it refers to the perspective of ontology, epistemology, and axiology. The integration-interconnection between both of them has three domains. First, they are interdependence-integrative. In other words, the relationship between science and religion is interdependent ontologically. Second, they are integrative-complement. It implies that the correlation between science and religion is complementary to each other epistemologically in terms of their applied methods. The method in science accepts scientific truth not only empirically and rationally but also intuitively or kasyfi. Third, they are integrative-qualification. 
It means that the relationship between science and religion has a reciprocal qualification axiologically in terms of all values they possess. As a whole, it implies that religious values science justify. As a result, it must be lightened by religious values.

The concept of Islamic value integration may adopt the idea proposed by Mulyadhi Kartanegara, Syed Naquib Al-Attas, and Ismail Rajhi Al-Faruqi. In addition to the concept of value integration, there is a bigger idea of the Islamization of Science that is proposed by the Muslim thinkers. Salafudin (2013) argues that the realization of Islamization of science uses several approaches, ranging from merely labelling, the axiological approach, the internalization of Islamic values, and the application of the principle of tawhid through Islamic education. The Islamization of science developed by Ismail Rajhi Al-Faruqi and Al-Attas. In al-Faruqi's view, the Islamic education system has been printed in a caricature of the West, where Western science has been detached from human values and dignity, spiritual values, and dignity with God. The same thing was conveyed al-Attas, the biggest challenge faced by Muslims is the challenge of knowledge spread throughout the Islamic world by Western civilization (Al-Attas, 2011 ; Afida, 2016; Soleh, 2016 ; Novayani, 2017; Mauliyah, 2016).

Al-Faruqi views that monotheism is something that substantially breaks the human identity entity in various dimensions. He proposed the understanding of Muslims towards monotheism to have an ideal value and to be more functional. The concept of monotheism should be promoted as a principle in the Islamization of science (Rijal, 2014; Zuhdiyah, 2016; Sholeh, 2017). The idea of Islamization of al-Faruqi was based on five basic principles; they are the oneness of God, the unity of creation, the unity of truth, the oneness of life and human unity (Soleh, 2011; Sholehuddin, 2010; Asnawan, 2017).

In this study, the concept of Islamic values integration in science is applied. Qadam (2015) notes the integration of science and religion has two meanings of typology. First, to reunite science and religion after the two are separated. Second, to establish science and religion as a primordial unity. Furthermore, Hasanah \& Zuhaida (2018) observed that in each subject, teachers must begin to deliver religious teaching contents in science learning by mentioning the Quranic verses which are closely related to natural phenomena. Thus, integration must be carried out at the operational level of learning. Misbahuddin (2015) records the unity of Science in Islam built on the foundation of the verses al-Matluwah (Qur'an) verses and alMajluwah (the universe) so that any discipline should be based on the epistemology of the Quran in the aspects of ontology, methodology, and its axiology.

The integration of Islamic values in sociology learning tools must be continuously improved. In this case, the principle of monotheism approach can be applied as one of the appropriate approaches to integrate Islamic values in a particular subject. Salafudin (2013) believed that the realization of the Islamization of science can be done using labeling, axiological approach, internalization approach to Islamic values, applying monotheistic principles, and Islamic education. In line with this, Naekun (2015: 31-32) investigated the integration of Islamic values in social sciences learning. This integration explored learners ' knowledge based on the environment or experience and provided a meaningful experience for learners.

The concept of monotheism serves as the most important principle of Islamic epistemology so that it plays a role as a basis for the integration of science. Al-Attas's view suggests that the concepts in contemporary science should be revised and then integrated with Islamic values. According to al-Faruqi, monotheism should be able to foster graduates who comprehends modern science, Islamic science, maintains the relevance of Islam to modern science, possess the ability to integrate Islamic science with creative modern science, and directs Islamic thought to be compatible with the rules set by Allah Subhanahu Wata'alâ Soleh 
(2011). Based on this perspective, Islamic values are in the position to be integrated in sociology and other subjects taught in the school.

The three previously mentioned concepts can be collaborated to design the integration of Islamic values in sociology learning. First, the integration requires the epistemological realm of sociology. Also, it is encouraged to conduct sociology studies based on Islamic teaching sources and scientific research results. As a result, those results of the studies can be claimed as Islamic sociology. Second, the concept of sociology adopted from the west, which offers several concepts contrary to Islamic teachings, should be revised. Third, there must be an effort to understand the relevance of Islam to sociology so that the effort to integrate Islamic science with sociology will be possible. In the level of implementation, Islamic values integration in sociology learning must be conducted systematically in curriculums, teaching content substances, learning methods, learning evaluation, and learning culture.

The concept of integration must be systematic starting from the philosophical paradigm to the operational curriculum development and learning process. It requires strategies to apply the concept starting from concept formulation, socialization, and application in the field. Therefore, there must be a formulation of an ideal integration concept in advance and then it should be socialized (Rifai et al., 2014)

When it comes to integrating Islamic values and sociological characters, a dialogue approach can be the option to explore. Noble characters taught in sociology such as religion, honesty, discipline, responsibility, care (mutual cooperation, cooperation, tolerance, and peace), politeness, responsiveness, and pro-activeness, can be integrated with the Islamic characters known as akblaq al-Karimah (noble characters) through a dialogue approach. Hidayat et al. (2019) reviewed the moral position in Islamic education. Moral is expected to be the fruit of the experience of Islamic teachings. Akblak should be educated and it takes process to realize in Islamic teachings. It integrates and encompasses aspects of sharia and morality.

Teaching material can be enriched using Islamic sociology postulated by Abdussalam based on the Quran. In addition, sociological concepts proposed by Islamic sociology scholars such as Ibn Khaldun who wrote his masterpiece in Muqaddimah, Ali-Shariaty, and Kuntowijoyo are valuable sources to explore. Ibn Khaldun thought which were written in his masterpiece has attracted scholars to study the books. Pribadi (2014) conducted a study on the important ideas of Ibn Khaldun by countering al-'Ibar wa Diwān al-Mubtada 'wa al-Khabar fi Ayyam al-'Arab wa al-'Ajam wa al-Barbar wa Man' Așarabum min Dhawi al-Sultän al-Akbar. The first volume known as Muqaddimah discusses 'ilm al-'Umran, and it is later known as sociology ('ilm al-Ijtima' $\imath$ ). Through his work, Ibn Khaldun is well-known as a pioneer of sociology and becomes a pioneer figure in social science. Ibn Khaldun has his own characteristics of sociological understanding in which the social phenomena as concrete data are integrated with Islamic values.

Two Islamic scholars who have a great contribution to Islamic sociology are Ali Syariati and Kuntowijoyo. Ali-Syariaty postulated his sociological thought based on Taubid or monotheism. This effort is relevant to the program of integrating monotheism on the basis and praxis of Islamic education in Indonesia. His contribution to sociology inspires the character education for Muslims and Indonesian people since he provided alternative solutions, enriched Islamic education in Indonesia, and encouraged continuously the Islamization of science (Sari, 2018). In Indonesia, Kuntowijoyo proposes his collection of ideas prophetic sociology. Jurdi (2010) ensures that according to Kuntowjoyo, the method of integration and interconnection in the framework of explaining social phenomena by linking with the text becomes the right choice to find scientific social science as scientific as those based on empirical observation. Uniquely, prophetic sociology has additional points because it 
is based on the truth of the text associated with social contexts or phenomena adopted into the text.

The planning of the integration of Islamic values in learning sociology can take many forms. It can be in the stages of justification of sociology teaching contents using the Quranic verses (Hidayat \& Syafe'i, 2018a). This effort must be appreciated to initiate and develop the integration of Islamic values in learning sociology. The integration can also be realized by integrating the substantial teaching contents and learning methods (Kholidah, 2015). Islamic values should also be integrated into institutional curriculum, learning methods, learning contents substance, learning evaluation, and learning culture. Given this pattern, the Qur'anic paradigm should be employed since it has the same foundation, monotheism.

Zainiyati (2014) conducted a study on several phases that can be used to apply Quranicparadigm learning. The phases include: first, mapping the concepts of secular and religious science; second, combining secular and religious scientific concepts; third, elaborating the relevant Qur'anic verses scientifically. The tradition of Islamic educational institutions such as congregational prayers, dhikr, Khatam Al-Quran, and Hafizh Al-Quran, infaq or charity must be cultivated. For Zainiyati, the phases of designing the integration of Islamic values in learning sociology are as follows: First, sociology teachers map the concepts of sociology and religious science first. Second, they combine the scientific concepts of sociology and a religious science. Third, they elaborate on the relevant Qur'anic verses scientifically. The culture of learning should nurture a religious climate. The tradition of pesantren can also be developed as a means of learning people' leadership.

In this study, Islamic values are integrated into learning sociology by employing a scientific approach. The approach includes discovery learning and problem-based learning, which can be applied as the learning model. Question and answer, interview, discussion, and role-playing can be applied in the classroom. The methods can be used to integrate character' education in a variety of educational components and even educational systems and learning systems (Rizal, 2012).

The learning resources used consist of sociology textbooks, worksheets, and personal experiences of teachers and students. The observed aspects are religious contents and characters which are realized through the dialogue approach. Teachers are supposed to commence teaching by delivering religious teaching contents. It can be done by mentioning the Qur'an verses that correlate with natural phenomena in the subject taught. Thus, the integration must be carried out at the operational level of learning (Hasanah \& Zuhaida, 2018). There are many methods available to carry out the integration. Syahidin (2009) developed AlNahlawi the Quranic Education Method. This method consists of story, Uswatun Hasanah, ibrah manizah, Tajribi, Amal, Hasanah Mawižoh, Hiwar, Jadal, Targhib wa Tarbib, tadabbur, and so on. Learning methods used in Pesantren traditions, such as sorogan, balagan, riblab and others can be taken into account. The conventional learning methods adopted from the west may be applied as long as they do not conflict with Islamic teachings. Contextual Teaching and Learning (CTL) model can be used as an alternative in that they accommodate the involvement of learners physically and mentally. This method allows students to solve problems together in the scientific framework Hidayat and Syahidin (2019). Teachers must be taught skill in developing learning materials and methods, so that they play the role to understand pedagogic competence (Hidayat \& Syafe'i, 2018b). They can explore learning methods in Pesantren tradition such as sorogan, balagan, riblah, poetry, to teach Islamic values.

Another aspect of education is evaluation. Hidayat, Rizal, and Fahrudin (2018a) examined that evaluations in Islamic education, which consisted of measurements and assessments. Evaluation should cover aspects of aqliyah, qolbiyah, and amaliah. Given this view, sociology learning evaluation must include the aspects of aqliyah, qolbiyah, and amalyiah. The 
first relates to the evaluation of the Islamic values that are integrated with the sociology teaching contents. The second has something to do with attitude evaluation. Finally, it concerns the evaluation of students' ability to follow learning processes and worship in daily life during school time.

Internalization of the monotheistic values can be done on all scientific teaching contents Darmana (2012). It can be done at the beginning, process, and end of the discussion of scientific teaching contents. In the beginning, the internalization is carried out to develop a reading culture and to study religion (Quranic verses or prophetic traditions), improve motivation, give directions, and build a foundation for learning science (Darmana, 2012). Based on Darmana's perspective, the internalization of monotheistic values in the learning culture must be done since the beginning, process, and end of learning. Sociology teachers must strive to create a religious atmosphere during the preliminary learning, and it is done not only in the first hour in all sessions in learning. Creating a religious atmosphere can also be done by reading Asmaul Husna, Kalimah Thoyyibah, the Quran, khatmil Quran prayer, and prayer for learning.

Sociology teachers must have a plan to guide students to use the principles of ta'lim learning actively and independently. They must be able to actualize sociological learning contents in daily life, learning evaluation, and sociology learning evaluation. They have a vital role in fostering the personality of students Cassum (2015), and creating a positive and conducive environment to create a good environment for student learning (Sayani, 2015). Teachers should also plan collaboration with students. Collaborative learning promotes and develops learning habits and lifelong learning. It will be convincing in producing high-quality and competitive students. Also, it is considered as the right method that helps students become more mature in the art of decision-making (Aderi et al., 2018).

Creating a religious atmosphere must be planned during core learning activities. It includes good teacher attitudes so that they will become role models. In the lesson plan, there must be a plan to create a religious atmosphere. This can be applied through learning methods such as the Quranic education method, the tradition of pesantren, sorogan, balagan, ribal, and other formats. The religious atmosphere also takes into account the discussion of sociological learning contents. The discussion is intended to raise awareness of grace and compassion, greatness and power, and gratitude to Allah Subhānahu Wata'älâ (Darmana, 2012). For Darmana, creating a religious atmosphere must also be done at the closing session of the learning activity. Sociology teachers should be able to bring into existence the meaningful learning of the lesson.

The study's results are expected to shed light on formulating a sociology learning system integrated with Islamic values. Then the results of this research can serve as an input for the development of sociology through social scientific studies. It should not only rely on empirical facts based on the positivistic paradigm as the only way to judge scientific truth. On the other hand, the findings can be taken into consideration in instilling the values of faith and piety and noble character through sociology learning. This research is limited to only one of the educational institutions. For further research, it is recommended to examine the design of the integration of Islamic values into sociology learning by comparing between various educational institutions. 


\section{CONCLUSION}

Based on the result and discussion above, it can be concluded that the design of the integration of Islamic values into sociology learning at SMA PGII 2 Bandung employed the 2013 curriculum instrument. The integration occurred in the level of justification models. In this regard, the Quran is used as a justification tool for sociology learning contents.

The references used in sociology learning were taken from secular or general sources and have not been integrated with Islamic values. In addition, the learning methods applied by the sociology teachers were taken from western methods, and they had not been integrated with Islamic values. Therefore, the internalization of monotheistic values in the learning culture can be initiated since the beginning, process, and, end of learning. Creating a religious atmosphere is necessary. It started from the beginning, middle, and, end of the learning process so that the phases of learning are supposed to be determined to reach those set objectives, including the monotheism paradigm.

\section{BIBLIOGRAPHY}

Abdussalam, A. (2014). Teori Sosiologi Islam (Kajian Sosiologis terhadap Konsep-konsep Sosiologi dalam Alquran Al-Karim). Jurnal Pendidikan Agama Islam -Ta'lim, 12(1), 25-40.

Aderi, M., Noh, C., Andayani, S., \& Yusuf, M. (2018). Collaborative Learning Technique within Higher Learning Education Students. Creative Education, 9, 2367-2375. https://doi.org/10.4236/ce.2018.914177

Afandi, R. (2011). Integrasi Pendidikan Karakter Dalam Pembelajaran IPS di Sekolah Dasar. Jurnal Pedagogia, 1(1), 85-98.

Afida, I. (2016). Pemikiran Tokoh Islamisasi Ilmu Pengetahuan: (Syed Muhammad Naquib Al-Attas). Falasifa, 7(2), 91-106.

Al-Attas, S. M. N. (2011). Islam and the Philosophy of Science. Prolegomena to the Metaphysics of Islam: An Exposition of the Fundamental Elements of the Worldview of Islam, 111-142.

Asnawan. (2017). Islamisasi Ilmu Pengetahuan, Wacana, Perspektif Al Faruqi. Adabiyah Jurnal Pendidikan Islam, 2(1), 1-18. https://doi.org/10.21070/ja.v2i1.1256

Bafadhol, I. (2015). Sekulerisme dan Pengaruhnya Dalam Dunia Pendidikan Islam. Edukasi Islami : Jurnal Pendidikan Islam, 04, 887-895.

Cassum, L. (2015). My Teaching and Learning Philosophy. Open Acces Library Journal, 1-4. https://doi.org/10.4236/oalib.1101290

Creswell, J. (2015). Riset Pendidikan: Perencanaa, Pelaksanaan, dan Evaluasi Riset Kualitatif \& Kuantitatif. Yogyakarta: Pustaka Pelajar.

Darmana, A. (2012). Internalisasi Nilai Tauhid Dalam Pembelajaran Sains. Jurnal Pendidikan Islam, XVII(1), 66-84.

Hasanah, N., \& Zuhaida, A. (2018). Desain Madrasah Sains Integratif: Integrasi Sains - Agama Dalam Pelaksanaan dan Perangkat Pembelajaran. Edukasia: Jurnal Penelitian Pendidikan Islam, 13(1), 155-180.

Hidayat, T., Rizal, A. S., \& Fahrudin. (2018). Pendidikan Dalam Perspektif Islam dan Peranannya Dalam Membina Kepribadian Islami. Jurnal Mudarrisuna: Media Kajian Pendidikan Agama Islam, 8(2), 218-244. https://doi.org/http://dx.doi.org/10.22373/jm.v8i2.3397 $0 \mathrm{Ta}$

Hidayat, T., \& Suryana, T. (2018). Menggagas Pendidikan Islam: Meluruskan Paradigma Pendidikan di Indonesia. Jurnal Pendidikan Islam Indonesia, 3(1), 75-91. Retrieved from http://ojs.pps-ibrahimy.ac.id/index.php/jpii/article/view/133/93 
Hidayat, T., \& Syafe'i, M. (2018a). Filsafat Perencanaan dan Implikasinya dalam Perencanaan Pembelajaran Pendidikan Agama Islam di Sekolah. Lentera Pendidikan, 21(2), 188-205. https://doi.org/https://doi.org/10.24252/lp.2018v21n2i5

Hidayat, T., \& Syafe'i, M. (2018b). Peran Guru Dalam Mewujudkan Tujuan Pembelajaran Pendidikan Agama Islam di Sekolah. Rayah Al-Islam: Jurnal Ilmu Islam, 2(1), 101-111.

Hidayat, T., \& Syahidin. (2019). Inovasi Pembelajaran Pendidikan Agama Islam Melalui Model Contextual Teaching And Learning Dalam Meningkatkan Taraf Berfikir Peserta Didik. Jurnal Pendidikan Agama Islam, XVI(2), 115. https://doi.org/10.14421/jpai.2019.162-01

Hidayat, T., Syahidin, \& Rizal, A. S. (2019). Prinsip Dasar Falsafah Akhlak Omar Mohammad $\mathrm{Al}$ - Toumy Al - Syaibany dan Implikasinya dalam Pendidikan di Indonesia. Jurnal Kajian Peradaban Islam, 2(1), 10-17. Retrieved from http://www.jkpis.com/index.php/jkpis/article/view/13/10

Jurdi, S. (2010). Sosiologi Islam \& Masyarakat Modern Teori,Fakta, dan Aksi Sosial. Jakarta: Kencana Prenada Media Group.

Kartanegara, M. (2005). Integrasi Ilmu : Sebuah Rekontruksi Holistik. Bandung: Arasy Mizan.

Kholidah, L. N. (2015). Pola Integrasi Nilai-Nilai Keislaman dalam Pembelajaran Pendidikan Agama Islam pada Lembaga Pendidikan. Jurnal At-Ta'dib, 10(2), 325-340. http://dx.doi.org/10.21111/at-tadib.v10i2.459

Makruf, J. (2009). New Trend of Islamic Education in Indonesia. Studia Islamika, 16(2), 243 290.

Mas'ud, Z. (2014). Axiology on the Integration of Knowledge, Islam and Science. Ta'lim, $21(2), 154-160$.

Mauliyah, A. (2016). Gerakan Islamisasi Ilmu Pengetahuan Naquib al-Attas. El-Banat: Jurnal Pemikiran Dan Pendidikan Islam, 6(1), 111-121. Retrieved from http://ejournal.kopertais4.or.id/susi/index.php/elbanat/article/view/2904

Misbahuddin, I. (2015). Epistemologi Al-Qur an Dalam Membangun Sains Islam. Teologia, 26(1), 3-15. http://dx.doi.org/10.21580/teo.2015.26.1.404

Mufid, F. (2014). Islamic Sciences Integration. QIJIS : Qudus International Journal of Islamic Studies, 2(2), 144-160. http://dx.doi.org/10.21043/qijis.v2i2.1565

Naekun, M. (2015). Integrasi Nilai-Nilai Agama Islam Dalam Pembelajaran IPS Sejarah Di Kelas VIII MTs Ma' aruf Wadas Kandangan Temanggung Tabun Pelajaran 2014/2015 (Tesis). Program Pascasarjana IAIN Salatiga.

Novayani, I. (2017). Islamisasi Ilmu Pengetahuan Menurut Pandangan Syed M. Naquib AlAttas dan Implikasi Terhadap Lembaga Pendidikan International Institute of Islamic Thought Civilization (ISTAC). Jurnal Al-Muta'alliyah, I(1), 74-89. Retrieved from http:// ejournal.kopertais4.or.id/sasambo/index.php/mutaaliyah/article/view/2812

Pribadi, M. (2014). Ibn Khaldun's Social Thought On Bedouin and Hadar. Al-Jami'ah, 52(2), 417-433. https://doi.org/10.14421/ajis.2014.522.417-433

Purwati, N., Zubaidah, S., Corebima, A. D., \& Mahanal, S. (2018). Increasing Islamic Junior High School Students Learning Outcomes through Integration of Science Learning and Islamic Values. International Jornal of Instruction, 11(4), 841-854. http://dx.doi.org/10.12973/iji.2018.11453a

Qadam, I. U. (2015). Kualitas Pendidikan Berbasis Filsafat Ilmu. Jurnal Penelitian, 9(2), 325346. http://dx.doi.org/10.21043/jupe.v9i2.1324

Rifai, N., Fauzan, Sayuti, W., \& Bahrissalim. (2014). Integrasi Keilmuan Dalam Pengembangan $\begin{array}{lllll}\text { Kurikulum di UIN } & \text { Te-Indonesia: }\end{array}$ https://doi.org/10.15408/tjems.v1i1.1108

Rijal, S. (2014). Epistemologi Tauhid Ismail R. Al-Faruqi. Miqot, XXXVIII(1), 21-44. http://dx.doi.org/10.30821/miqot.v38i1.49 
Rizal, A. S. (2012). Model Pendidikan Nilai Integratif Dalam Tradisi Pesantren Modern (Penelitian Interpretatif-Hermeneutis terbadap Fenomena Pendidikan di PP Al-Basyariab). Bandung: Pascasarjana Universitas Pendidikan Indonesia (Disertasi).

Salafudin. (2013). Islamisasi Ilmu Pengetahuan. Forum Tarbiyah, 11(2), 194-216. Retrieved from http://ejournal.uika-bogor.ac.id/index.php/ FIKRAH\%0Ahttp://moraref.or.id/ record/view/47180

Sari, Z. (2018). Relevansi Pemikiran Sosiologi Islam Ali Syariati dengan Problematika Pendidikan Islam di Indonesia. Zamah Sari, 7(2), 194-213. https://doi.org/10.32832/tadibuna.v7i2.1354

Sayani, A. H. (2015). My Philosophy of Teaching and Learning. Open Acces Library Journal, 2-5. https://doi.org/10.4236/oalib.1102109

Sholeh. (2017). Islamisasi Ilmu Pengetahuan ( Konsep Pemikiran Ismail Raji Al-Faruqi dan Syed Muhammad Naquib Al-Attas ). Jurnal Al-Hikmah, 14(2), 209-221. https://doi.org/10.25299/al-hikmah:jaip.2017.vol14(2).1029

Sholehuddin, M. S. (2010). Ismail Raji Al-Faruqi The Founding Father Islamisasi Pengetahuan. Forum Tarbiyah, 8(2), 203-214.

Soleh, A. K. (2011). Mencermati Konsep Islamisasi Ilmu Ismail R Faruqi. Ulul Albab, 12(1), 80-95. https://doi.org/10.18860/ua.v0i0.2398

Soleh, Achmad Khudori. (2016). Integrasi Ilmu (Islam dan Barat) Pemikiran Ismail Rajhi Al-Faruqi. Yogyakarta: Arruzz Media.

Suaidi, S. (2014). Islam dan Modernisme. Islamuna, 1(1), 49-61.

Suparto, \& Zamakhsari, A. (2015). Rekonstruksi Pemikiran Membangun Pendidikan Integratif Nondikotomik. Edukasi : Jumal Penelitian Pendidikan Agama Dan Keagamaan, 13(2), 179_ 200. http://dx.doi.org/10.32729/edukasi.v13i2.238

Syahidin. (2009). Menelusuri Metode Pendidikan Dalam al-Quran. Bandung: Alfabeta.

Taskun, O. (2014). An exploratory examination of Islamic values in science education: Islamization of science teaching and learning. Sult Stud of Sci Edu, 9, 855-875. https://doi.org/10.1007/s11422-013-9553-0

Zainiyati, H. S. (2014). Desain Pengembangan Kurikulum Integratif. Nadwa: Jurnal Pendidikan Islam, 8(2), 295. http://dx.doi.org/10.21580/nw.2014.8.2.583

Zuhdiyah. (2016). Islamisasi Ilmu Ismail Raji Al-Faruqi. Tadrib, II(2), 1-21. Retrieved from http://jurnal.radenfatah.ac.id/index.php/Tadrib/article/view/1173 